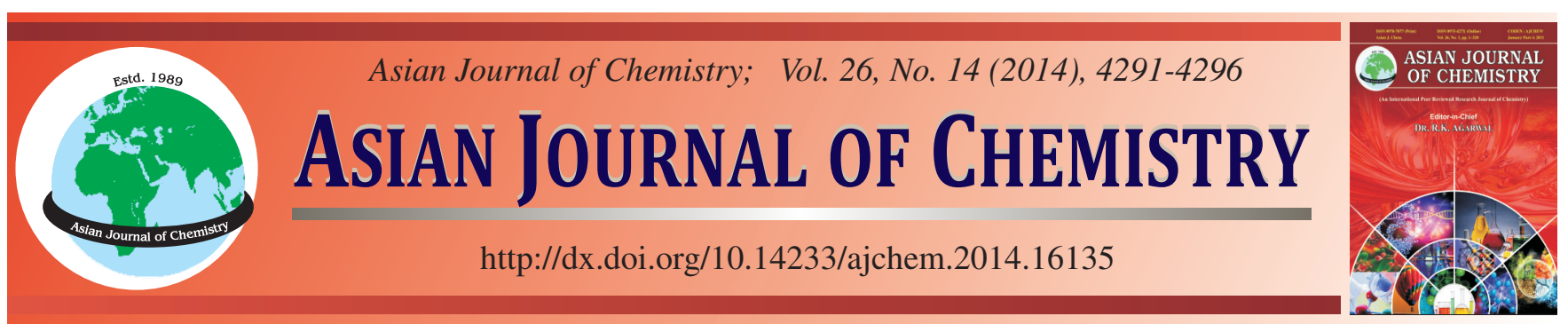

\title{
Efficiency of Advanced Oxidation Processes for Detoxification of Industrial Effluents
}

Munawar Iqbal ${ }^{1,2, *}$, Ijaz Ahmad Bhatti ${ }^{1, *}$, Muhammad Zia-ur-Rehman ${ }^{3}$, Haq Nawaz Bhatti $^{1}$ and Muhammad Shahid $^{1}$

${ }^{1}$ Department of Chemistry and Biochemistry, University of Agriculture, Faisalabad-38040, Pakistan

${ }^{2}$ National Center of Excellence in Physical Chemistry, University of Peshawar, Peshawar-25120, Pakistan

${ }^{3}$ Pakistan Council of Scientific and Industrial Research (PCSIR) Laboratories Complex, Lahore, Pakistan

*Corresponding author: E-mail: bosalvee@yahoo.com

Received: 1 August 2013;

Accepted: 8 January 2014;

Published online: 5 July 2014;

AJC-15461

\begin{abstract}
The possibility of applying photo-catalytic treatment $\left(\mathrm{UV} / \mathrm{H}_{2} \mathrm{O}_{2} / \mathrm{TiO}_{2}\right)$ to reduce the cytotoxicity and mutagenicity as well as the microbial load of soap and detergent wastewater has been investigated. Wastewater from three soap and detergent industries were collected from Faisalabad, Gujranwala and Sargodha regions of Pakistan. Bioassays such as allium cepa, haemolytic and brine shrimp were utilized to assess the cytotoxicity, while mutagenicity was evaluated through Ames test. The microbial load; bacterial count and total coliform tests were performed under standardized conditions. Along with toxicity appraisal, the water quality parameter such as BOD, COD, DO, pH, TDS and TSS were also measured before and after application of $\mathrm{UV} / \mathrm{H}_{2} \mathrm{O}_{2} / \mathrm{TiO}_{2}$ treatment. A considerable reduction in cytotoxicity and mutagenicity was achieved with the maximum degradation of pollutants. With the application of advanced oxidation treatment complete removal of cytotoxicity and mutagenicity was obtained and results indicate that the advanced oxidation process can be successfully used for toxicity removal, for the improvement of water quality parameters and hence the treated wastewater could possibly be used for irrigation purposes.
\end{abstract}

Keywords: Advanced oxidation process, Bioassays, Soap and detergent, Wastewater, Cytotoxicity and mutagenicity.

\section{INTRODUCTION}

From last few decades, there is a growing concern of chemical pollution due to their harmful effect on living organisms. The water bodies serve as temporary or final receptors of diverse variety of contaminants, which are consequently contaminating the watersheds and adjoining territories ${ }^{1,2}$. The rapid stride in industrialization is a major concern which is jeopardizing the ecological balance ${ }^{3}$. Among the damages caused by chemical agents to exposed organisms, genotoxic and mutagenic effects have shown to be worrying, which can lead to several health problems and also affect future generations due to inheritable alterations in genetic material. Genetic toxicology involved in detecting compounds capable of causing genetic damage with the aim of understanding potential biological penalty ${ }^{4,5}$.

The effluents discharged from industries enter into the water bodies in several different ways, either dumped directly, such as industrial effluents, or from wastewater treatment plants that do not fulfill their obligations. Due to universal solubility nature of water, almost all kinds of substances can be transported and distributed more easily in the water cycle $e^{6,7,8}$. At present, the safe disposal of industrial wastewater is one of the major ecological challenges. Therefore, environmental degradation has now become a global problem and to main- taining the ecosystem health is a serious issue being confronted by the environmentalist. Due to mixing of untreated wastewater with watersheds and adjoin territories, the water bodies are getting polluted day by day and are responsible for adverse effects on soil, aquatic life, agriculture as well as all other types of flora and fauna in biosphere because of toxic and persistence chemical nature. Disposal of industrial effluents into fresh water bodies disturbs water quality parameters of water such as $\mathrm{BOD}, \mathrm{COD}, \mathrm{DO}$, colour and $\mathrm{pH}$, which are necessary to sustain aquatic life, primary productivity and food chain $^{9,10}$. If the safety of wastewater discharged from industries is assured by industrialists or by pollution control boards, then treated industrial wastewater may be potentially used for fish production, irrigation for non-edible cash crop, aquaculture and for many other such types of multifarious uses ${ }^{11-13}$.

Over the last decade there has been a rapid growth in the use of detergents. Despite the increased usage, relatively little work has been focused on the environmental effects, especially surfactant which are known endocrine disruptor due to weak ability to mimic estrogen and in turn disrupt the natural balance of hormones in affected organisms ${ }^{14}$. Overall, most of the losses to the environment occur at the use phase and for the purposes of exposure modeling it is assumed that $100 \%$ emission to sewer occurs at the post consumer stage ${ }^{15}$. The annual production of 
detergents in the USA, Western Europe and Japan is $6 \times 10^{6}$ tones. The wastewaters from the manufacturing of detergents, which contain residual product material, can have a variable polluting load and, if left untreated, can have an appreciable impact on the environment, especially cytotoxicity, genotoxicity and mutagenicity ${ }^{16}$.

As a result of exposure to contaminated water containing toxic agent, negative impact ranging from cytotoxicity to mutagenicity in various models (plants and animal) have been documented well ${ }^{4,5,17,18}$. Toxicant screening in environmental samples using method in vitro are reliable to measure the extent of pollution load and this biological assessment is compulsory for effluent monitoring, discharged from industries before being mixed with water bodies ${ }^{19,20}$.

In present study, the soap and detergent wastewater sample were collected from different cities of Punjab, Pakistan and their water quality parameters were evaluated. The cytotoxicity and mutagenicity were also measured using different bioassays. After preliminary evaluation, the soap and detergent wastewater was subjected to advanced oxidation process and finally the water quality parameter as well as their cytotoxicity and mutagenicity potential was evaluated in order to ensure whether the treatment efficiency and reusability of treated wastewater in industry and agriculture.

\section{EXPERIMENTAL}

The wastewater samples were collected from three soap and detergent industries (Gujranwala, Faisalabad and Sargodha of Pakistan) ( $n=3$ ) using standard methods. Briefly, dried plastic gallon (washed with distilled water and drenched in $1 \% \mathrm{HNO}_{3}$ for $24 \mathrm{~h}$ ) was used to collect the water samples. Sampling was performed for three days for each industry and one sample was collected three times per day. After filling the gallons were immediately sealed and transported to the of water toxicity laboratory bioassay section and radiation chemistry laboratory, Department of Chemistry and Biochemistry, University of Agriculture, Faisalabad, Pakistan. The collected wastewater samples were stored at $-4{ }^{\circ} \mathrm{C}$ to avoid any type of change in wastewater before treatment.

Treatment of soap and detergent wastewater by advanced oxidation process: The UV radiation source was a low pressure UV lamp (44 Watt, emission at $253.7 \mathrm{~nm}$, Galvano Scientific, Pakistan) which was protected by a quartz tube. During irradiation, temperature was maintained at $25 \pm 2{ }^{\circ} \mathrm{C}$. The solution was projected at the bottom of the reactor at a distance of $6 \mathrm{~cm}$. All independent variables were optimized using factorial design by analyzing the data through response surface methodology (RSM) for maximum degradation. Finally the treatment levels were selected where maximum degradation was observed and for toxicity evaluation, the soap and detergent wastewater sample were treated at optimized conditions.

Water quality parameter measurement: Before use all instruments were properly calibrated, water quality parameters of wastewater such as $\mathrm{pH}, \mathrm{DO}, \mathrm{BOD}$ and COD were analyzed by $\mathrm{pH}, \mathrm{DO}, \mathrm{BOD}$ (Method 5210 B, Aqualytic BOD-OxiDirect) and COD meters, while TSS and TDS were measured by standard methods before and after treatments ${ }^{21}$. Briefly, well- mixed samples were filtered; the filtrate was evaporated to dryness in a pre-weighed china dish and dried to constant weight at $180{ }^{\circ} \mathrm{C}$. The increase in dish weight represents the total dissolved solids. The amount of TDS was measured using following relation;

Total dissolved solids $(\mathrm{mg} / \mathrm{L})=(\mathrm{A}-\mathrm{B}) \times$ 1000/Sample volume, $(\mathrm{mL})$

where $\mathrm{A}=$ weight of dried residue $+\operatorname{dish}(\mathrm{mg})$ and $\mathrm{B}=$ weight of dish (mg).

For the measurement of TSS, a well-mixed sample was filtered in pre-weighed filter paper. The filter paper was kept for $1 \mathrm{~h}$ at 103 to $105{ }^{\circ} \mathrm{C}$ in an oven, cooled in a desiccators, weighed and TSS was measured by following relation;

Total suspended solids $\mathrm{mg} / \mathrm{L}=(\mathrm{A}-\mathrm{B}) \times$

1000/Sample volume $(\mathrm{mL})$

where $\mathrm{A}=$ weight of dried residue + filter paper and $\mathrm{B}=$ weight of filter paper

All water quality parameters were reported as percentage decrease or increase and were calculated with following formulae;

WQP $(\%)$ increase or decrease $=\{($ Value before treatment-

Values after treatment)/Value before treatment $\} \times 100$

Toxicity evaluation: Hydrogen peroxide itself is toxic and to avoid the $\mathrm{H}_{2} \mathrm{O}_{2}$ effect, it was important to eliminate it from irradiated solutions. To remove $\mathrm{H}_{2} \mathrm{O}_{2}$, small amounts of $\mathrm{MnO}_{2}(<1 \mathrm{mg} / \mathrm{mL})$ were added to the solutions ${ }^{22}$. After a reaction time of $1 \mathrm{~h}$, the solutions were filtered and subjected to the toxicity tests such as microbial laod, Allium cepa, haemolytic, brine shrimp and Ames bioassays. The $\mathrm{TiO}_{2}$ was also separated before toxicity evaluation of treated samples by centrifugation at $14000 \mathrm{rpm}$ for $5 \mathrm{~min}$ and the supernatant was collected for toxicity evaluation.

\section{Cytotoxicity}

Allium cepa test: The root initiation and growth assessment was done using the procedure of modified A. test $t^{23}$. Onion bulbs of equal size of same species were purchased from local market, Faisalabad, Pakistan. The bases of the bulbs were gently scrapped and root primordia were exposed to wastewater. Before transformation of bulbs in tested solution, bulbs were germinated in tap water for each treatment and finally, best five were transferred in wastewater along with negative and positive control under same conditions. The germinated bulbs were kept in solution for $48 \mathrm{~h}$ and the tested samples were replaced with the gap of $6 \mathrm{~h}$. Ultra-pure water was used as a negative control and methyl methanesulfonate (MMS) (Sigma-Aldrich) was used as a positive control. The roots were harvested after $48 \mathrm{~h}$ period and transferred in acetone-alcohol (1:3). The root tips were hydrolyzed in $1 \mathrm{~N} \mathrm{HCl}$ at $60{ }^{\circ} \mathrm{C}$ until they become soft and number of root and their lengths were counted, measured and obtained values were averaged.

Haemolytic assay: Three $\mathrm{mL}$ of young and healthy sheep blood cells were gently mixed, poured into a sterilized $15 \mathrm{~mL}$ polystyrene screw-cap tube $(15 \mathrm{~mL})$ and centrifuged for $5 \mathrm{~min}$ at $4200 \mathrm{rpm}$. The supernatant was poured off and the viscous pellet was washed three times with $5 \mathrm{~mL}$ of chilled $\left(4^{\circ} \mathrm{C}\right)$ sterile isotonic phosphate buffer saline (PBS) solution $(\mathrm{NaCl}$, $8 \mathrm{~g} / \mathrm{L} ; \mathrm{KH}_{2} \mathrm{PO}_{4}, 0.2 \mathrm{~g} / \mathrm{L} ; \mathrm{Na}_{2} \mathrm{HPO}_{4}, 1.2 \mathrm{~g} / \mathrm{L} ;$ and $\mathrm{KCl}, 0.2 \mathrm{~g} / \mathrm{L}$, adjusted to $\mathrm{pH} 7.4$, using $1 \mathrm{M} \mathrm{NaOH}$ and $1 \% \mathrm{HCl}$ solution 
and mixed for $1 \mathrm{~h}$ to stabilize $\mathrm{pH}$ ). The washed cells were suspended in a final volume of $20 \mathrm{~mL}$ chilled, sterile PBS and the cells counted on a haemacytometer. The blood cell suspension was maintained on wet ice and diluted with sterile PBS to $7.068 \times 10^{8}$ cells $\mathrm{m} / \mathrm{L}$ for each assay and sample $(20 \mu \mathrm{L})$ was aseptically poured into $1.5 \mathrm{~mL}$ Appendrof tubes. For each assay, $0 \cdot 1 \%$ Triton $\mathrm{X}-100$ was used as the positive control (100\% lytic), while PBS was used as negative control (0\% lysis). Diluted blood cell suspension $(180 \mu \mathrm{L})$ were aseptically poured into each $1.5 \mathrm{~mL}$ tube and gently mixed three times with a wide mouth pipette tip. Appendrof tubes were incubated for $35 \mathrm{~min}$ at $37{ }^{\circ} \mathrm{C}$ with agitation ( $80 \mathrm{rev} / \mathrm{min}$ ) and immediately, were placed on ice for $5 \mathrm{~min}$ and finally, centrifuged for $5 \mathrm{~min}$ at $1310 \times \mathrm{g}$. A $100 \mu \mathrm{L}$ of supernatant was carefully collected, placed into a sterile $1.5 \mathrm{~mL}$ appendrof tube and diluted with $900 \mu \mathrm{L}$ chilled and sterile PBS. All tubes were maintained on wet ice after dilution and their absorbance at $576 \mathrm{~nm}$ were measured on $\mu$ quant (BioTek, Winooski, VT, $\mathrm{USA})^{24}$. All the samples were run in triplicate and results were averaged. The percentage lysis of RBC was measured using following relation;

$\%$ RBCs lysis $=($ Absorbance of sample $/$

Absorbance of Triton X-100) $\times 100$

Brine shrimp assay: Brine shrimp eggs, Artemia salina L. were hatched in artificial seawater prepared by dissolving $38 \mathrm{~g}$ of sea salt in $1 \mathrm{~L}$ of distilled water and $\mathrm{pH}$ of the solution was adjusted to 8.5. After $48 \mathrm{~h}$ incubation at $26-30{ }^{\circ} \mathrm{C}$ under constant aeration, the larvae (nauplii) were attracted to one side of the vessel with a light source and collected with the help of pipette. Nauplii were separated from eggs by aliquoting them three times in small beakers containing seawater. Wastewater samples and model compound aqueous solution were dissolved in DMSO and diluted with artificial sea salt water so that final DMSO concentration did not exceed $0.05 \%$ and $50 \mathrm{~mL}$ of sample was placed in one sample tube and a two-fold dilution carried out down the column of sample tubes. The last sample tube was left with sea salt water and DMSO only to serve as control. The total volume was adjusted to $5 \mathrm{~mL}$ with sea salt water and $100 \mathrm{~mL}$ of suspension of nauplii containing 20 larvae and tubes were incubated for $24 \mathrm{~h}$. The tubes were then examined under a magnifying glass and the numbers of dead nauplii were counted in each tube counted. Cyclophosphamide $(10 \mu \mathrm{g} / \mathrm{mL})$ was used as a positive control in all experiments. The percentage lethality was determined by comparing the mean surviving larvae of the test and control tubes $^{25}$.

Ames test (mutagenicity assay): The Ames test was performed in agar plate as precisely reported elsewhere ${ }^{26}$. The plates were sealed in plastic bags and incubated at $37{ }^{\circ} \mathrm{C}$ for 4 days. The blank plate was observed first and the rest of plates were read only when all wells in the blank plate showed purple colour indicating the assay was not contaminated. The background, standard and test plates were scored visually and all yellow, partial yellow or turbid wells were scored as positive wells, while purple wells were scored as negative. The wastewater sample was considered toxic to the test strain if all wells in the test plate showed purple colouration. For an extract to be mutagenic, the number of positive wells had to be more than twice the number of positive well in the background plate $^{27}$.

\section{RESULTS AND DISCUSSION}

The water quality parameters of soap and detergent wastewater, before treatment, are given in Table-1. The measured $\mathrm{pH}, \mathrm{DO}, \mathrm{COD}$, TDS and BOD were beyond the permissible limit which were found to be in following rage; $\mathrm{pH}$ 11.0-11.6, DO 1.7-2.01 mg/L, COD 1350-1500 mg/L, TDS 1289-1370 $\mathrm{mg} / \mathrm{L}$, TSS 700-790 mg/L and BOD 550-700 mg/L.

Effect of advanced oxidation process on cytotoxicity and microbial load reduction: The wastewater samples collected from different soap and detergent units were subjected to UV radiation treatment in the presence of hydrogen peroxide and titanium dioxide and various independent variables (hydrogen peroxide and titanium dioxide concentration, UV exposure time, $\mathrm{pH}$ and shaking) were optimized for maximum degradation of the pollutants as well as for the improvement of water quality parameters. Finally, the effect of advanced oxidation process under investigation on cytotoxicity and mutagenicity reduction of effluents was evaluated on the basis biological and toxicological tests such as microbial load, haemolytic, shrimp, allium cepa and Ames tests. The toxicity of soap and detergent wastewater observed before and after the application of $\mathrm{UV} / \mathrm{H}_{2} \mathrm{O}_{2} / \mathrm{TiO}_{2}$ are shown in Table-2. The wastewater were treated by UV radiation (UV power 44 watt) having concentration of $\mathrm{TiO}_{2}(5.93 \%)$ and $\mathrm{H}_{2} \mathrm{O}_{2}(4.39 \%)$ at shaking speed of $150 \mathrm{rpm}$ and UV exposure for $100 \mathrm{~min}$. A significant reduction in microbial load and cytotoxicity was recorded. The total bacterial and total coliform population was recorded to be $>1 \times 10^{6}$ and $>1 \times 10^{5}$ cuf and after treatment both the microbes were not detected. The Allium cepa tests showed that the UV treatment in the presence of hydrogen peroxide and titinium dioxide has promising efficiency to reduce the cytotoxic effect of soap and detergent effluents. Before treatment the number of roots and root lengths were recorded to be in the range 10-11 and 3.2-4.1 cm, respectively and after treatment, the increase in number of roots and root lengths were 44.44 and $50.75 \%$, respectively. Heamolytic assay also showed that after UV treatment of wastewater in the presence of hydrogen peroxide and titanium dioxide, there was a significant reduction in RBCs lysis. Before treatment, the RBC death was up to $69 \%$, while after treatment maximum

TABLE-1

WATER QUALITY PARAMETERS OF SOAP AND DETERGENT INDUSTRY WASTEWATER BEFORE TREATMENT

\begin{tabular}{ccccccc}
\hline S. No. & $\mathrm{pH}$ & $\mathrm{DO}(\mathrm{mg} / \mathrm{L})$ & $\mathrm{COD}(\mathrm{mg} / \mathrm{L})$ & $\mathrm{TDS}(\mathrm{mg} / \mathrm{L})$ & $\mathrm{TSS}(\mathrm{mg} / \mathrm{L})$ & $\mathrm{BOD}(\mathrm{mg} / \mathrm{L})$ \\
\hline Sargodha $(\mathrm{n}=3)$ & $11.6 \pm 0.63$ & $1.8 \pm 0.6$ & $1500 \pm 71.5$ & $1165 \pm 58.25$ & $700 \pm 82.7$ & $600 \pm 35$ \\
Faisalabad $(\mathrm{n}=3)$ & $11.5 \pm 0.53$ & $1.7 \pm 0.15$ & $1700 \pm 76.5$ & $1370 \pm 68.50$ & $750 \pm 62.62$ & $700 \pm 40$ \\
Gujranwala $(\mathrm{n}=3)$ & $11.0 \pm 0.58$ & $2.01 \pm 0.7$ & $1350 \pm 64.25$ & $1289 \pm 64.45$ & $790 \pm 37.00$ & $550 \pm 41$ \\
\hline
\end{tabular}

*DO-dissolve oxygen, COD-chemical oxygen demand, BOD-biological oxygen demand, TDS-total dissolves solid and TSS-total suspended solids 


\begin{tabular}{|c|c|c|c|c|c|c|}
\hline \multicolumn{7}{|c|}{$\begin{array}{l}\text { TABLE-2 } \\
\text { MICROBIAL LOAD AND CYTOTOXICITY OF SOAP AND DETERGENT WASTEWATER BEFORE AND } \\
\text { AFTER TREATMENT EVALUATED THROUGH BIOLOGICAL (TOTAL BACTERIAL AND TOTAL } \\
\text { COLIFORM COUNT) AND TOXICOLOGICAL (Allium cepa, haemolytic and shrimp test) TEST }\end{array}$} \\
\hline & Microbial test & & Allium сера & & Haemolytic & Shrimp test \\
\hline \multirow[t]{2}{*}{ Before treatment } & TBC & Total coliform & Root count & Root length & Cell death & death \\
\hline & $(\mathrm{CFU})$ & (CFU) & & $(\mathrm{cm})$ & $(\%)$ & $(\%)$ \\
\hline Industry $1(\mathrm{n}=3)$ & $>1 \times 10^{6}$ & $1 \times 10^{5}$ & $10 \pm 0.20$ & $3.2 \pm 0.04$ & $69 \pm 1.1$ & $61 \pm 0.60$ \\
\hline Industry $2(\mathrm{n}=3)$ & $>1 \times 10^{6}$ & $1 \times 10^{5}$ & $11 \pm 0.19$ & $3.7 \pm 0.03$ & $68 \pm 1.2$ & $60 \pm 0.52$ \\
\hline Industry $3(n=3)$ & $>1 \times 10^{6}$ & $1 \times 10^{5}$ & $10 \pm 0.22$ & $4.1 \pm 0.03$ & $67 \pm 0.9$ & $59 \pm 0.61$ \\
\hline PC & ---- & ---- & $15 \pm 0.26$ & $7.0 \pm 0.11$ & $100 \pm 0.0$ & $100 \pm 0.0$ \\
\hline $\mathrm{NC}$ & 0.000 & 0.000 & $11 \pm 0.20$ & $3.0 \pm 0.02$ & 0.0000 & 0.0000 \\
\hline \multicolumn{7}{|l|}{ After treatment } \\
\hline Industry $1(n=3)$ & ND & ND & $17 \pm 0.40$ & $6.5 \pm 0.12$ & $14 \pm 0.35$ & $09 \pm 0.21$ \\
\hline Industry $2(\mathrm{n}=3)$ & ND & ND & $16 \pm 0.32$ & $7.3 \pm 0.25$ & $17 \pm 1.01$ & $10 \pm 0.19$ \\
\hline $\begin{array}{c}\text { Industry } 3(\mathrm{n}=3) \\
\% \text { reduction }\end{array}$ & ND & ND & $18 \pm 0.51$ & $6.9 \pm 0.09$ & $16 \pm 0.16$ & NR \\
\hline Industry $1(n=3)$ & 100 & 100 & 41.00 & 50.76 & 79.71 & 85.24 \\
\hline Industry $2(\mathrm{n}=3)$ & 100 & 100 & 31.25 & 49.31 & 75.00 & 83.33 \\
\hline Industry $3(n=3)$ & 100 & 100 & 44.44 & 40.57 & 76.11 & ---- \\
\hline \multicolumn{7}{|c|}{$\begin{array}{l}\text { TBC-total bacterial count, TC-total coliform, ACT-Allium cepa test, NR-not recorded, ND-not detected, P } \\
\text { n-sample seeded in triplicate } \\
\text { For haemolytic test, PC and NC were TritonX-100 }(0.1 \%) \text { and phosphate buffer saline, respectively } \\
\text { For ACT, PC and NC were distilled water and methyl methanesulfonate (MMS) }(10 \mathrm{mg} / \mathrm{L}) \text {, respectively } \\
\text { For shrimp test, PC and NC were cyclophosphamide }(10 \mu \mathrm{g} / \mathrm{mL}) \text { and sea water, respectively }\end{array}$} \\
\hline
\end{tabular}

death was recorded to $17 \%$ and overall, $\mathrm{RBC}$ death reduction was up to $79.71 \%$. Similar to Allium ceap and haemolytic, Brine shrimp test also showed a significant reduction in cytotoxicity after UV treatment along with hydrogen peroxide and titanium dioxide. The brine shrimp nauplii death before treatment was recorded up to $61 \%$ and after treatment nauplii death rate decreased considerably and up to $85.24 \%$ reduction was observed (Table-2).

Before treatment the soap and detergent wastewater was found to be mild mutagenic in nature and after the application of advanced oxidation process $\left(\mathrm{UV} / \mathrm{TiO}_{2} / \mathrm{H}_{2} \mathrm{O}_{2}\right)$, no matuagenic activity of sample was observed. Before treatment 58 (TA98) and 63 (TA100) plates out of 98 were affected and after treatment number of affected plates reduced considerably which were 29 (TA98) and 32 (TA100). The reduction in mutagenic activity of soap and detergent was up to $57.7 \%$ (TA98) and $58.73 \%$ (TA100), respectively (Table-3). From the results of
Ames assay, it can be concluded that photo-catalysis (UV/ $\mathrm{TiO}_{2} / \mathrm{H}_{2} \mathrm{O}_{2}$ ) has the ability to reduce the mutagenic activity of mutagenic agent.

The advanced oxidation processes have been widely used in water and wastewater treatment for the degradation and mineralization of organic and inorganic contaminants as well as to improve degradability of industrial wastewater. In the last years, different AOP's have been investigated for the removal of emerging contaminants from urban wastewater effluents ${ }^{28}$ and drinking water ${ }^{29}$. Unfortunately, the partial oxidation of organic contaminants may result in the formation of more toxic intermediates than parent compounds. In order to avoid this drawback, AOP's are expected to be carefully operated and monitored and toxicity tests should be used to evaluate toxicity of treated effluent ${ }^{30}$. Parameters such as $\mathrm{pH}$, DO, BOD, COD, TDS and TSS are generally used for quality evaluation of wastewater. These quality parameters cannot be

TABLE-3

MUTAGENICITY OF SOAP AND DETERGENT WASTEWATER EVALUATED THROUGH AMES TEST BEFORE AND AFTER APPLICATION OF UV RADIATION TREATMENT IN THE PRESENCE OF HYDROGEN PEROXIDE AND TITANIUM DIOXIDE

\begin{tabular}{ccc|cc}
\hline & & & \multicolumn{2}{c}{ TA100 } \\
\hline & Affected plates & Total plates & Affected plates & Total plates \\
\hline Industry 1 $(\mathrm{n}=3)$ & $58 \pm 2.35$ & 96 & $63 \pm 2.60$ & 96 \\
Industry 2 $(\mathrm{n}=3)$ & $52 \pm 1.9$ & 96 & $59 \pm 2.90$ & 96 \\
Industry 3 $(\mathrm{n}=3)$ & $55 \pm 2.85$ & 96 & $57 \pm 1.90$ & 96 \\
Positive control & $19 \pm 0.50$ & 96 & $21 \pm 0.60$ & 96 \\
Negative control & 0.000 & 96 & 0.000 & 96 \\
After treatment & $27 \pm 0.90$ & 96 & $26 \pm 0.60$ & 96 \\
Industry 1 $(\mathrm{n}=3)$ & $22 \pm 0.70$ & 96 & $33 \pm 0.48$ & 96 \\
Industry 2 $(\mathrm{n}=3)$ & $29 \pm 0.72$ & 96 & $32 \pm 0.85$ & - \\
Industry 3 $(\mathrm{n}=3)$ & 53.44 & - & 58.73 & - \\
\% reduction & 57.7 & - & 44.06 & - \\
Industry 1 $(\mathrm{n}=3)$ & 47.27 & - & 43.85 & \\
Industry 2 $(\mathrm{n}=3)$ & & & & \\
Industry 3 $(\mathrm{n}=3)$ & & & & \\
\hline
\end{tabular}

For Ames test, positive control for TA98 and TA100 were $\mathrm{K}_{2} \mathrm{Cr}_{2} \mathrm{O}_{7}(0.01 \mathrm{~g} / \mathrm{L})$ and $\mathrm{NaN}_{3}(0.5 \mu \mathrm{g} / 100 \mu \mathrm{L})$, respectively and background (without standard and tested compound) was used as negative control 
used for evaluation of toxic effect on receiving water bodies. The best way to evaluate effluent toxicity effect, it is necessary to use bioassays ${ }^{5,31,32}$. Different organisms such as culture cells, fish, algae, bacteria, shrimp, higher plant and other microorganisms may be used for this purpose. It is reported that the effluent meets all physicochemical requirements, regarding its toxicity, it may cause considerable negative effects on living organisms ${ }^{5,32-34}$. In this regard, attempt have been carried out to study the toxicity of industrial wastewater after the application of advanced oxidation processes by various researchers $^{35-40}$. In view of importance of advanced oxidation process (UV treatment in combination with hydrogen peroxide and titanium dioxide), the present study was performed whether the treated soap and detergent wastewater using advanced oxidation process was biologically fit or not. The toxicity of effluents was evaluated through cytotoxicity and mutagenic assays. The microbial population before and after application of UV in the presence of hydrogen peroxide and titanium dioxide was also performed and resultantly, even a microbe was not detected. Similarly, the cytotoxic and mutagenic assay also showed that the soap and detergent wastewater samples were safe after treatment. Other then reduction in cytotoxicity and mutagenicity of soap and detergent wastewater, the water quality parameter were also improved significantly. The maximum improvement in water quality parameter was recorded where sample were treated by UV radiation (UV power 44 watt) for 100 min using $\mathrm{TiO}_{2}(3-7 \%)$ and $\mathrm{H}_{2} \mathrm{O}_{2}(4.39 \%)$ at shaking speed of $150 \mathrm{rpm}$. The reduction in COD and BOD were observed up to 48 and $52 \%$ for $3 \% \mathrm{TiO}_{2}$, by increasing the $\mathrm{TiO}_{2}$ concentration to $5 \%$, the reduction in COD and BOD were observed 61 and $68 \%$, respectively and no considerable reduction in $\mathrm{COD}$ and $\mathrm{BOD}$ observed on further increasing the concentration of $\mathrm{TiO}_{2}(7 \%)$. Through RSM analysis, it was observed that maximum reduction in COD and BOD took place for $\mathrm{TiO}_{2}$ concentration of $3.66 \%$. The $\mathrm{pH}$ of the solution reduced significantly after $\mathrm{UV} / \mathrm{TiO}_{2} / \mathrm{H}_{2} \mathrm{O}_{2}$ treatment which is considered as a good efficiency of the treatment. Before treatment the $\mathrm{pH}$ of soap and detergent wastewater was in the alkaline range (11.0-11.6) and after $\mathrm{UV} / \mathrm{TiO}_{2} / \mathrm{H}_{2} \mathrm{O}_{2}$ treatment, it turned to acidic side (5.4-6.3). Similarly, the TDS and TSS values of soap and detergent wastewater were also reduced significantly to the level of 45 and $46 \%$ after treatment for $3 \% \mathrm{TiO}_{2}$. However, TDS and TSS reduction was enhanced to 64 and $77 \%$ using $5 \% \mathrm{TiO}_{2}$. The radiation treatment in the presence of $\mathrm{H}_{2} \mathrm{O}_{2}$ and $\mathrm{TiO}_{2}$ increased the $\mathrm{DO}$ value up to $66 \%$ of soap and detergent treated wastewater and the reduction in mutagenicity and cytotoxicity was also high with the significant improvement in water quality parameter. It has also been reported previously that UV treatment in the presence of $\mathrm{H}_{2} \mathrm{O}_{2}$ has significant effect on toxicity reduction as well as to improve the water quality parameters ${ }^{37}$; however, the efficiency of UV treatment in the presence of $\mathrm{TiO}_{2}$ along with hydrogen peroxide was found pronounced. Toxicological tests also showed that the $\mathrm{UV} / \mathrm{H}_{2} \mathrm{O}_{2} / \mathrm{TiO}_{2}$ treatment system was very effective and efficient for the reduction of toxicity and results of present study were found to be similar to the previous studies ${ }^{35-40}$. Some author studied the toxicity of treated water by other bioassays; however positive results have been reported. Toxicity of four types of industrial wastewater, treated by Fenton's reagent, was analyzed using bioluminescent bacteria Vibrio fischeri NRRL B-1117741, microtox toxicity of textile dyes ${ }^{42}$ and Daphnia magna toxicity test also of textile wastewater ${ }^{38}$.

\section{Conclusion}

The UV radiation treatment in the presence of hydrogen peroxide and titanium dioxide appear to represent promising efficiency for the treatment of soap and detergent wastewater. Photo-catalytic treatment reduced significantly the cytotoxicity and mutagenicity as well as microbial load. For toxicity elicit, it seems that the treatment condition must be optimized because this could be due to the formation of intermediates originating from the degradation of pollutants by virtue of incomplete degradation. From results of toxicity reduction and improvement in water quality parameter of soap and detergent wastewater treated by $\mathrm{H}_{2} \mathrm{O}_{2} / \mathrm{UV} / \mathrm{TiO}_{2}$, it is suggested that the treated wastewater could be used for industrial reuse, irrigation and aquaculture, etc.

\section{ACKNOWLEDGEMENTS}

The financial support of Higher Education Commission (HEC) of Pakistan for the research project "Radiation Treatment of Industrial of Wastewater" (Project No. 20-1346/R\&D/ 09/5892) is greatly acknowledged.

\section{REFERENCES}

1. D.T. Sponza, Ecotoxicol. Environ. Saf., 54, 74 (2003).

2. J. Bianchi, E.L.G. Espindola and M.A. Marin-Morales, Ecotoxicol. Environ. Saf., 74, 826 (2011).

3. S. Tabrez, S. Shakil, M. Urooj, G.A. Damanhouri, A.M. Abuzenadah and M. Ahmad, J. Environ. Sci. Health., 29, 250 (2011).

4. D.M. Leme and M.A. Marin-Morales, Mutat. Res. Genet. Toxicol. Environ. Mutagen., 650, 80 (2008).

5. D.M. Leme and M.A. Marin-Morales, Mutat. Res. Rev. Mutat. Res., 682, 71 (2009).

6. B. Malmqvist and S. Rundle, Environ. Conserv., 29, 134 (2002).

7. I. Oller, S. Malato and J.A. Sánchez-Pérez, Sci. Total Environ., 409, 4141 (2011).

8. J. Bai, H. Xu, Y. Zhang, Z. Peng and G. Xu, Biochem. Eng. J., 70, 115 (2013).

9. N.N. Rao, K.M. Somasekhar, S.N. Kaul and L. Szpyrkowicz, J. Chem. Technol. Biotechnol., 76, 1124 (2001).

10. M. Auriol, Y. Filali-Meknassi, R.D. Tyagi, C.D. Adams and R.Y. Surampalli, Process Biochem., 41, 525 (2006).

11. M. Wong, Chemosphere, 50, 775 (2003).

12. V.K. Singh and J. Singh, J. Environ. Biol., 37, 385 (2006).

13. M. Molinos-Senante, F. Hernández-Sancho and R. Sala-Garrido, J. Environ. Manage., 92, 3091 (2011).

14. J. Jaworska, H. Van Genderen-Takken, A. Hanstveit, E. van de Plassche and T. Feijtel, Chemosphere, 47, 655 (2002).

15. M.A. Karim, Pesticide Profiles: Toxicity, Environmental Impacts and Fate, CRC Lewis Publishers, Boca Raton (1997).

16. V.S. Houk, Mutat. Res. Rev. Genet. Toxicol., 277, 91 (1992).

17. C.K. Grisolia, M.R. Bilich and L.M. Formigli, Ecotoxicol. Environ. Saf., 59, 123 (2004).

18. M.M. Hoshina and M.A. Marin-Morales, Ecotoxicol. Environ. Saf., 72, 2090 (2009).

19. F.P. Rodrigues, J.P.F. Angeli, M.S. Mantovani, C.L.B. Guedes and B.Q. Jordao, Genet. Mol. Biol., 33, 169 (2010).

20. J. Margot, C. Kienle, A. Magnet, M. Weil, L. Rossi, L.F. de Alencastro, C. Abegglen, D. Thonney, N. Chèvre, M. Schärer and D.A. Barry, Sci. Total Environ., 461-462, 480 (2013).

21. A.D. Eaton, L.S. Glesceri, E.W. Rice and A.E. Greenberg, Standard Methods for the Examination of Water and Wastewater, American Public Health Association, Washington, edn 21 (2005). 
22. S. Weihua, Z. Zheng, A.S. Rami, Z. Tao and H. Desheng, Radiat. Phys. Chem., 65, 559 (2002).

23. N.E. Abu and K. Mba, J. Toxicol. Environ. Health Sci., 3, 44 (2011).

24. W.A. Powell, C.M. Catranis and C.A. Maynard, Lett. Appl. Microbiol., 31, 163 (2000).

25. M.H. Moshafi, F. Sharififar, G. Dehghan and A. Ameri, Iran. J. Pharm. Res., 8, 59 (2010).

26. D.M. Maron and B.N. Ames, Mutat. Res. Environ. Mutag. Relat. Subj., 113, 173 (1983).

27. B. Jolibois and M. Guerbet, Ann. Occup. Hyg., 50, 189 (2005).

28. V. Naddeo, L. Rizzo and V. Belgiorno. Water, Wastewater and Soil Treatment by Advanced Oxidation Processes (AOPS), Lulu, Raleigh, NC (2011).

29. S. Sanches, M.T. Barreto Crespo and V.J. Pereira, Water Res., 44, 1809 (2010).

30. L. Rizzo, S. Meric, M. Guida, D. Kassinos and V. Belgiorno, Water Res., 43, 4070 (2009).

31. G. Tchobanoglous, F. Burton and H. Stensel, Wastewater Engineering Treatment and Reuse, Metcalf and Eddy. Inc. McGraw-Hill Company, edn 4 (2003).

32. H. Movahedian, B. Bina and G. Asghari, Iran. J. Environ. Health Sci. Eng., 2, 2 (2005).
33. P. Radix, M. Léonard, C. Papantoniou, G. Roman, E. Saouter, S. Gallotti-Schmitt, H. Thiébaud and P. Vasseur, Ecotoxicol. Environ. Saf., 47, 186 (2000).

34. C.R. Oliveira-Martins and C.K. Grisolia, Genet. Mol. Biol., 32, 853 (2009).

35. S. Gomes de Moraes, R. Sanches Freire and N. Duran, Chemosphere, 40, 369 (2000).

36. G. Tezcanli-Guyer and N. Ince, Ultrason. Sonochem., 10, 235 (2003).

37. R. Andreozzi, L. Campanella, B. Fraysse, J. Garric, A. Gonnella, R. Lo Giudice, R. Marotta, G. Pinto and A. Pollio, Water Sci. Technol., 50, 23 (2004).

38. H. Selcuk, Dyes Pigments, 64, 217 (2005).

39. M.H. Pérez, G. Peñuela, M.I. Maldonado, O. Malato, P. FernándezIbáñez, I. Oller, W. Gernjak and S. Malato, Appl. Catal. B, 64, 272 (2006).

40. N.M. Mahmoodi and M. Arami, J. Photochem. Photobiol. B, 94, 20 (2009).

41. K. Barbusinski, Pol. J. Environ. Stud., 14, 11 (2005).

42. A.S. Koparal, Y. Yavuz, C. Gürel and Ü.B. Ögütveren, J. Hazard. Mater., 145, 100 (2007). 